\title{
IMPLIKASI MEKANISMECORPORATE GOVERNANCE, LEVERAGE, AUDIT TENURE DAN KUALITAS AUDIT TERHADAP INTEGRITAS LAPORAN KEUANGAN
}

\author{
Ida Ayu Ratih Manuari ${ }^{1}$ \\ Ni Luh Nyoman Sherina Devi \\ Program Studi Akuntansi, Fakultas Ekonomi dan Bisnis,
Universitas Mahasaraswati Denpasar, Bali, Indonesia ${ }^{1,2}$
email: ratih.manuari@gmail.com
}

\begin{abstract}
Financial reports are used by entities to convey financial conditions tostakeholders. Financial reports are expected to have integrity, which means that they have truthful and reliable information.This study aims to analyze the effect of corporate governance mechanisms, leverage, audit tenure and audit quality on the integrity of financial statements in financial sector companies listed on the Indonesia Stock Exchange.The sample was selected using a purposive sampling method. The data analysis technique used is multiple linear regression. The results showed that institutional ownership, managerial ownership, independent commissioners, and audit committee had no effect on the integrity of financial statements. Leverage and audit tenure were found to have a negative effect, and audit quality has a positive effect on the integrity of financial statements.Therefore, companies are expected to pay attention to the level of leverage ratios and audit services, thus the level of integrity of financial statements can always be improved.
\end{abstract}

Keywords: Audit tenure, audit quality, good corporate governance, integrity of financial reporting, leverage.

\section{PENDAHULUAN}

Standar Akuntansi Keuangan

PSAK No.1 (Ikatan Akuntan Indonesia, 2013:04) menyebutkan laporan keuangan merupakan laporan yang secara periodic dibuat menurut prinsip akuntansi yang berterima umum mengenai keadaan keuangan dari individu, asosiasi maupun kelompok bisnis. Laporan posisi keuangan, laporan laba rugi, laporan perubahan ekuitas, laporan arus kas, dan catatan atas laporan keuangan adalah bagian dari lapran keuangan. Laporan digunakan oleh entitas untuk menyampaikan situasi yang terkait dengan kondisi keuangan kepada para pihak yang memiliki kepentingan internal maupun eksternal.

Integritas laporan keuangan merupakan istilah yang merujuk pada seberapa jauh laporan keuangan memberikan informasi yang jujur dan sebenar-benarnya. Informasi akuntansi wajib menangkup tiga karakteristik kualitatif informasi akuntansi, yang mencakup relevansi, objektivitas, dan reliabilitas.

Kasus ketidakjujuran dalam laporan keuangan memiliki kaitan yang erat dengan masalah integritas laporan keuangan. Kasus yang pernah terjadi melibatkan perusahaan besar 
yang sebelumnya berkualitas audit tinggi di Amerika, yaitu Enron, Global Crossing, Tyco, serta Worldcom (Susiana \& Herawaty, 2007). Di tahun 2001 Enron mengakui keuntungan senilai US\$ 600 , namun ternyata sesungguhnya Enron mengalami kerugian. Sedangkan di Indonesia, kasus yang pernah terjadi melibatkan PT. Lippo Tbk dan PT. Kimia Farma Tbk. Pada kasus tersebut, terbukti ada kecurangan akuntansi yang melibatkan pihak-pihak seperti Chief Executive Officer (CEO), komisaris, komite audit, dan internal auditor. Perkara manipulasi data keuangan yang kerap terjadi mengindikasikan bahwa penyajian informasi dalam laporan keuangan kurang berintegritas bagi yang berkepentingan.

\section{Good Corporate Governance} (GCG) merupakan segenap aturan yang menentukan hubungan antara pemilik saham, pengurus, kreditur, pemerintah, pegawai, dan pemegang kepentingan intern dan ekstern lainnya berkaitan dengan hak dan kewajibannya masing-masing. (Tristiarini, 2005). Pelaku bisnis saat ini dituntut untuk mengembangkan, mengaplikasikan sistem dan pandangan yang baru dalam mengelola bisnis, yakni berprinsip pada good corporate governance.

Penerapan GCG dapat dilihat dari indicator seperti persentase kepemilikan saham manajemen, kepemilikan saham institusional, keberadaan komite audit, dan keberadaan proporsi dewan komisaris. Pada kenyataannya mekanisme GCG belum sepenuhnya diterapkan oleh seluruh perusahaan (Susiana \& Herawaty, 2007). Padahal penerapan GCG diharapkan dapat meningkatkan integritas laporan keuangan yang disusun oleh perusahaan. Aplikasi terhadap good corporate governance dapat mempengaruhi laporan keuangan yang dihasilkan, karena pihak manajemen akan lebihsulit melakukan kecurangan dalam pelaporan keuangan. Hal ini karena adanya monitoring oleh dewan komisaris, sehingga laporan keuangan dapat lebih berintegritas.

Leverage merupakan istilah pendayagunaan aset dan sumber (sources of funds) oleh perusahaan dengan biaya tetap dengan tujuan meningkatkan keuntungan potensial pemilik saham (Sartono, 2008:257). Perusahaan dapat mengaplikasikan kebijakan hutang (leverage) supaya dapat memperoleh keuntungan lebih tinggi daripada biaya aset dan sumber dananya, yang akan berujung pada peningkatan keuntungan pemilik saham.

Audit tenure merupakan jumlah tahun KAP atau auditor dalam memberikan jasa audit untuk perusahaan. Pemerintah mengatur tempo perikatan audit yaitu maksimal 6 tahun perikatan untuk KAP dan 3 tahun perikatan untuk seorang akuntan publik yang tertulis dalam Keputusan Menteri Keuangan Nomor 17/PMK.01 Tahun 2008 tentang Jasa Akuntan Publik Pasal 3. Santia dan Afriyenti (2019) menemukan hasil bahwa audit tenure berpengaruh negatif terhadap integritas laporan keuangan. Lamanya hubungan auditee dan auditor akan mengurangi independensi auditor yang berimbas pada terganggunya independensi auditor dalam menjalankan tugas. Panjangnya masa perikatan auditor akan menimbulkan kedekatan yang berakibat pada menurunnya kualitas auditor dalam mengaudit laporan 
keuangan klien. Namun lain halnya dengan temuan Setiawan (2016) yaitu audit tenure berpengaruh positif terhadap integritas laporan keuangan. Makin panjang tenur KAP menimbulkan pengetahuan auditor/KAP dalam menjalankan audit secara profesional, dan juga menimbulkan cost lebih rendah, serta meningkatkan ketelitian auditor. Namun Ismail (2018) dan Pratiwi (2019) menemukan audit tenure tidak berpengaruh pada integritas laporan keuangan dalam risetnya.

Kualitas audit menunjukkan probabilitas auditor untuk mampu melaporkan temuannya dengan baik mengenai eksistensi pelanggaran yang berlangsung dalam sistem akuntansi klien. Eskalasi kualitas audit dapat dilihat dari seberapa berguna dan berharganya jasa yang diberikan KAP, maka KAP diharapkan bertindak menjunjung profesionalisme tinggi (Susiana \& Herawaty, 2007).

Berdasarkan inkonsistensi hasil penelitian sebelumnya, peneliti mencoba untuk meneliti kembali mengenai pengaruh mekanisme corporate governance, leverage, audit tenure dan kualitas audit terhadap integritas laporan keuangan pada perusahaan sektor keuangan yang terdaftar di Bursa Efek Indonesia. Corporate governance akan diukur menggunakan variabel kepemilikan institusional, kepemilikan manajerial, komisaris independen dan komite audit.

Tujuan penelitian ini adalah menguji dan menganalisis pengaruh mekanisme corporate governance, leverage, audit tenure dan kualitas audit terhadap integritas laporan keuangan pada perusahaan sektor keuangan yang terdaftar di Bursa
Efek Indonesia. Hasil penelitian ini diharapkan dapat memberikan manfaat baik secara teoritis dan praktis, seperti kontribusi terhadap peran monitoring auditor dan penerapan good corporate governance dalam melakukan pengawasan terhadap tindakan manajemen sehingga dapat dipastikan bahwa manajemen bertindak sebaik yang dapat dilakukannya untuk kepentingan perusahaan.

\section{TINJAUAN PUSTAKA \\ Teori Keagenan (Agency Theory)}

Hubungan antara agen (manajemen) dan prinsipal (pemilik usaha) dijelaskan oleh Teori Keagenan (Jensen \& Meckling, 1976). Hubungan tersebut dapat berujung pada situasi ketidakseimbangan informasi (asymmetrical information). Ini disebabkan karena agen memiliki informasi lebih banyak tentang perusahaan daripada prinsipal. Teori agensi menyebutkan jika terdapat pemisahan antara pemilik sebagai prinsipal dan manajemen sebagai agen yang menjalankan perusahaan dapattimbul permasalahan agensi karena tiap pihak akancenderung berusaha untuk memaksimalkan fungsi utilitasnya. Hal ini akan berimbas pada integritas dari laporan keuangan pada perusahaan.

\section{Integritas Laporan Keuangan}

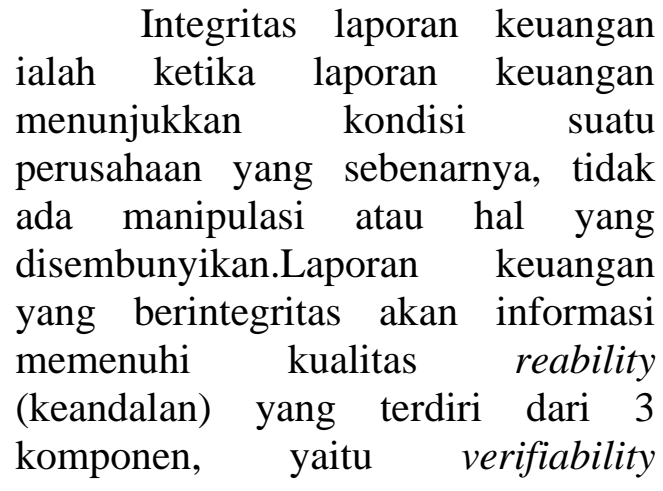


(menghasilkan pendapat yang sama), representational faith fulness (penyajian yang tulus dan jujur) dan neutrality (tidak memihak).

\section{Mekanisme Corporate Governance}

Corporate

governance

didefinisikan sehagai susunan aturan kreditur, pemerintah, karyawan, serta stakeholder internal dan eksternal sesuai hak dan tanggung jawabnya (FCGI, 2001).Apabila konsep GCG diaplikasikan dengan baik, diharapkan pertumbuhan ekonomi juga meningkat seiring dengan semakin baiknya transparansi pengelolaan perusahaan.

Unsur-unsur

corporate governance yang digunakan mengacu pada unsur internal dengan menggunakan unsur pemegang saham yaitu kepemilikan sahan oleh pihak institusi yang disebut dengan kepemilikan institusional, kepemilikan saham oleh pihak manajemen yang disebut dengan kepemilikan manajerial, unsur dewan komisaris yang dilihat dari persentase keberadaan dewan komisaris independen dalam suatu perusahaan atau disebut dengan proporsi komisaris independen dan komite yang mengaudit operasi dan keadaan yang disebut dengan komite audit.

\section{Leverage}

Leverage adalah rasio yang mengukur sejauh mana aktiva perusahaan dibiayai menggunakan utang (Kasmir, 2016:112). Perusahaan yang memiliki tingkat leverage tinggi menghadapi risiko keuangan cenderung tinggi karena ditakutkan menemui kesulitan keuangan karena utang yang besar. Rasio ini memberi gambaran struktur modal perusahaan dan menunjukkan tingkat risiko tak tertagih dari suatu utang. Perusahaan yang memiliki tingkat leverage tinggi cenderung melakukan pengungkapan laporan keuangan yang lebih luas. Tujuannya agar pemegang saham perusahaan tidak meragukan kinerja manajemen perusahaan dan yakin bahwa haknya sebagai kreditur akan terwujudkan.

\section{Audit Tenure}

Audit tenure merupakan masa jabatan dari Kantor Akuntan Publik (KAP) saatsecara perofesional melaksanakan jasa audit terhadap kliennya (Setiawan, 2016). Audit tenure adalah jangka waktu kerja sama antara KAP dan auditee. Ketentuan ini diatur dalam Peraturan Pemerintah Nomor 20 Tahun 2015 pasal 11 yang menjelaskan bahwa pemberian jasa audit terhadap laporan keuangan dari suatu perusahaan dilakukan oleh KAP paling lama untuk lima tahun buku berturut-turut. Auditor bisa menerima kembali penugasan audit untuk klien setelah dua tahun buku tidak memberikan jasa audit umum atas laporan keuangan klien tersebut (Saad \& Abdillah, 2019).

Lestari (2015) berpendapat bahwa perikatan auditor dan kliennya akan menimbulkan kedekatan sehingga ditakutkan dapat mengurangi independensi auditor serta kualitas audit dalam mengaudit laporan keuangan klien. Lamanya hubungan auditor-klien akan mempengaruhi kecenderungan auditor dalam mengeluarkan opininya. Pergantian auditor dibutuhkan supaya kualitas audit dalam proses pelaporan keuangan meningkat.

\section{Kualitas Audit}

Segala kemungkinan auditor mampu mendapat temuan pelanggaran dalam sistem akuntansi klien saat melakukan audit laporan 
keuangan dan melaporkannya dalam laporan keuangan auditan, merupakan definisi kualitas audit. Dalam menjalankan tugasnya itu, auditor mengacu pada standar auditing dan kode etik akuntan publik yang relevan. Kualitas audit penting dan berperan penting mewujudkan laporan keuangan yang dapat reliabel sebagai dasar pengambilan keputusan (Hardiningsih, 2010). Namun dalam pelaksanaan tugasnya, auditor cenderung terlibat konflik kepentingan dengan manajemen. Manajemen mengharapkan kinerja perusahaannya tampak sukses, seperti yang tersirat pada tingginya laba.

\section{Pengaruh Kepemilikan Intitusional} Terhadap Integritas Laporan Keuangan

Kepemilikan institusional adalah kepemilikan saham perusahaan yang dikuasai oleh institusi ataupun lembaga lain (Nilawati, 2018). Balina (2015) menyarankan pentingnya sistem pengawasan dalam perusahaan, salah satunya melalui penggalakkan monitoring melalui investor-investor institusional. Monitoring atau pengawasan oleh pihak investor institusional diharapkan memotivasi manajer agar lebih memfokuskan perhatiannya pada kinerja perusahaan, yang akan mengurangi tingkat perilaku oportunis atau mementingkan kepentingan sendiri. Kepemilikan institusional diharapkan mampu menurunkan konflik kepentingan serta meningkatkan integritas dari laporan keuangan.

Giovani (2016) meneliti perusahaan pertambangan di BEI dan menemukan kepemilikan institusional berpengaruh positif dan signifikan terhadap integritas laporan keuangan. Hal ini selaras dengan penelitian
Suyitno (2016) dan Susiwo (2018) dengan hasil penelitian kepemilikan institusional berpengaruh positif terhadap integritas laporan keuangan. Berdasarkan uraian tersebut, maka hipotesis pertama yang dikembangkan adalah:

$\mathrm{H}_{1}$ : Kepemilikan intitusional berpengaruh positif terhadap integritas laporan keuangan.

\section{Pengaruh Kepemilikan Manajerial Terhadap Integritas Laporan Keuangan}

Kepemilikan manajerial adalah kepemilikan saham yang dipegang pihak manajemen yang sekaligus sebagai pengelola perusahaan. Meningkatnya kepemilikan manajerial akan mengurangi risiko tindakan manipulasi. Kepemilikan manajemen dapat memadankan kepentingan manajemen dengan pemegang saham, sehingga mampu mengurangi masalah yang ditimbulkan oleh agency theory (Nilawati, 2018). Besarnya kepemilikan saham akanmelibatkan manajemen secara langsung dalam merasakan manfat dari keputusan yang diambil dan menanggung akibat dari kesalahan pengambilan keputusan.

Balina (2015) yang meneliti perusahaan manufaktur di BEI dengan hasil kepemilikan manajerial berpengaruh positif terhadap integritas laporan keuangan. Riset Pradani (2017) serta Santia dan Afriyenti (2019) juga menemukan kepemilikan manajerial berpengaruh positif terhadap integritas laporan keuangan. Berdasarkan uraian di atas, maka hipotesis kedua yang dikembangkan adalah: 
Journal of Applied Management and Accounting Science. (JAMAS)

(Ida Ayu Ratih Manuari, Ni Luh Nyoman Sherina Devi 116 - 131)

Vol 2, No 2, Juni 2021

\begin{abstract}
$\mathrm{H}_{2}$ : Kepemilikan manajerial berpengaruh positif terhadap integritas laporan keuangan.

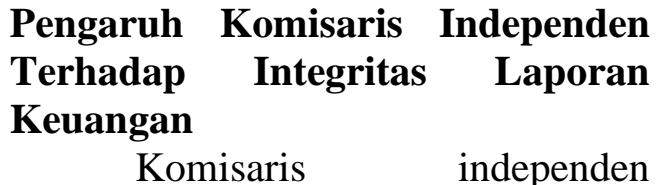
merupakan anggota dewan komisaris yang bersumber dari luar emiten. Tujuan adanya komisaris independen adalah menyepadankan pengambilan keputusan khususnya dalam rangka melindungi pemegang saham minoritas dan kelompok lain yang terkait. Komisaris independen bisa berperan sebagai penengah jika muncul perseteruan di antara manajer internal dan memonitoring kebijakan manajer dan juga memberi nasihat kepada manajemen. Jika perusahaan memiliki komisaris independen, laporan keuangan yang disusun manajemen cenderung lebih berintegritas.
\end{abstract}

Ariastini (2017) menemukan
bahwa komisaris independen
berpengaruh positif terhadap
integritas laporan keuangan karena
dewan komisaris yang independen
dapat mengawasi proses pelaporan
keuangan dengan baik. RisetVerya et
al.(2016) dan Susiwo (2018) juga
menyatakan bahwa komisaris
independen berpengaruh positif
signifikan terhadap integritas laporan
keuangan. Sehingga hipotesis ketiga
yang dikembangkan adalah:
$\mathrm{H}_{3}:$ Komisaris independen
berpegaruh positif terhadap

\section{Pengaruh Komite Audit Terhadap} Integritas Laporan Keuangan

Komite Audit adalah komite yang disusun oleh dewan direksi yang bertugas melaksanakan pengawasan independen atas proses laporan keuangan dan audit ekstern.
Berdasarkan keputusan Ketua Bapepam dan LK dengan No: KEP496/BL/2008 mensyaratkan bahwa wajib membentuk komite audit dengan anggota minimal 3 orang bagi perusahaan yang telah go public. Komite audit menjadi salah satu upaya untuk mengurangi tingkat manipulasi dalam penyajian laporan keuangan.

Suyitno (2016) meneliti perusahaan manufaktur yang terdaftar di BEI dengan hasil komite audit berpengaruh positif terhadap integritas laporan keuangan. Susiwo (2018) melakukan penelitian pada perusahaan manufaktur yang terdaftar di BEI dengan hasil penelitian yang menyatakan bahwa komite audit berpengaruh positif signifikan terhadap integritas laporan keuangan. Berdasarkan uraian di atas, maka hipotesis keempat yang dikembangkan dalam penelitian ini adalah:

$\mathrm{H}_{4}$ : Komite audit berpegaruh positif terhadap intergritas laporan keuangan.

Pengaruh Leverage Terhadap Integritas Laporan Keuangan

Rasio leverage mengukur besarnya aktiva yang berasal dari hutang atau modal, untuk mengetahui posisi perusahaan dan kewajibannya (Gayatri \& Suputra, 2013). Tingginya leverage akan meningkatkan risiko investor sehingga cenderung menuntut perusahaan untuk memperoleh keuntungan yang besar. Situasi ini memprovokasi manajemen untuk melangsungkan manajemen laba sehingga menurunkan tingkat integritas laporan keuangan (Fajaryani, 2015).

Pernyataan ini didukung oleh hasil penelitian dari Yulinda et al.(2016) yang melakukan penelitian 
pada perusahaan manufaktur yang terdaftar di BEI dengan hasil penelitian leverage berpengaruh negatif terhadap integritas laporan keuangan. Susiwo (2018) melakukan penelitian pada perusahaan manufaktur yang terdaftar di BEI juga menemukan bahwa leverage berpengaruh negatif signifikan terhadap integritas laporan keuangan. Hipotesis kelima yang dikembangkan adalah:

$\mathrm{H}_{5}$ : Leverage berpengaruh negatif terhadap integritas laporan keuangan.

Pengaruh Audit Tenure Terhadap Integritas Laporan Keuangan

Audit Tenure adalah masa perikatan dari Kantor Akuntan Publik (KAP) dalam memberikan jasa audit terhadap kliennya. Lestari (2015) menemukan bahwa audit tenureberpengaruh negatif terhadap integritas laporan keuangan. Hasil penelitian ini juga didukung oleh Santia \& Afriyenti (2019) yang melakukan penelitian pada perusahaan properti dan real estate yang terdaftar di BEI yang menyatakan bahwa audit tenure berpengaruh negatif dan tidak signifikan terhadap integritas laporan keuangan. Berdasarkan uraian di atas, maka hipotesis keenam dalam penelitian ini adalah:

$\mathrm{H}_{6}$ : Audit tenure berpengaruh negatif terhadap integritas laporan keuangan.

Pengaruh Kualitas Audit Terhadap Integritas Laporan Keuangan

Kualitas audit adalah suatu kemungkinan dimana auditor dapat melaporkan temuannya dengan baik atau tidak tentang adanya suatu pelanggaran yang terjadi dalam sistem akuntansi kliennya. Untuk dapat menghasilkan kualitas audit yang baik, auditor perlu menempuh pelatihan-pelatihan untuk mengasah kemampuannya. Pelatihan khusus bagi auditor bertujuan untuk meningkatkan mutu personal dan meningkatkan keahlian khusus di salah satu bidang sehingga laporan yang dihasilkan juga memiliki integritas yang tinggi (Tussiana \& Lastanti, 2017).

Penelitian Badewin (2019) menunjukkan bahwa variabel kualitas audit yang diproksikan dengan ukuran KAP berpengaruh terhadap integritas laporan keuangan. Hal tersebut didukung oleh Suyitno (2016) dan Adhitya (2018) yang menemukan bahwa kualitas audit berpengaruh positif terhadap integritas laporan keuangan. Sehingga hipotesis ketujuh dalam penelitian ini adalah:

$\mathrm{H}_{7}$ : Kualitas audit berpegaruh positif terhadap intergritas laporan keuangan.

\section{METODE PENELITIAN}

Lokasi penelitian yang dilakukan oleh peneliti adalah di perusahaan sektor keuangan yang terdaftar pada Bursa Efek Indonesia (BEI), data diperoleh dengan mengakses melalui website www.idx.co.id. Objek penelitian adalah laporan keuangan dan informasi-informasi yang terdapat dalam laporan tahunan (annual report) perusahaan sektor keuangan yang terdaftar di Bursa Efek Indonesia (BEI).

Data kuantitatif yang digunakan adalah data yang berasal dari laporan tahunan perusahaan sektor keuangan yang terdaftar di Bursa Efek Indonesia tahun 20162018.Data sekunder yang digunakan dalam penelitian ini adalah laporan keuangan tahunan (annual report) perusahaan sektor keuangan yang 
Journal of Applied Management and Accounting Science. (JAMAS)

(Ida Ayu Ratih Manuari, Ni Luh Nyoman Sherina Devi 116 - 131)

Vol 2, No 2, Juni 2021

menjadi sampel selama periode pengamatan tahun 2016 - 2019 yang terdaftar di Bursa Efek Indonesia (BEI).

Metode penentuan sampel dalam penelitian ini adalah metode purposive sampling dengan kriteria:

1) Perusahaan sektor keuangan yang terdaftar di BEI berturut-turut untuk periode 2016-2019.
2) Perusahaan sektor keuangan yang laporan keuangannya (annual report) dapat diunduh/diakses untuk periode 2016-2019.

3) Perusahaan sektor keuangan yang menerbitkan laporan keuangan dalam satuan mata uang Rupiah.

4) Perusahaan sektor keuangan yang memiliki data lengkap dalam periode penelitian.

Tabel 1

Metode Penentuan Sampel

\begin{tabular}{llc}
\hline No. & \multicolumn{1}{c}{ Kriteria } & Jumlah \\
\hline 1 & $\begin{array}{l}\text { Perusahaan sektor keuangan yang terdaftar di BEI sampai dengan } \\
2019 .\end{array}$ & 90 \\
\hline 2 & $\begin{array}{l}\text { Perusahaan sektor keuangan yang laporan keuangannya (annual report) } \\
\text { tidak dapat diakses untuk periode 2016 - 2019. }\end{array}$ & $(20)$ \\
\hline 3 & $\begin{array}{l}\text { Perusahaan sektor keuangan yang menerbitkan laporan keuangan } \\
\text { dalam satuan mata selain uang Rupiah. }\end{array}$ & 0 \\
\hline $4 \quad \begin{array}{l}\text { Perusahaan sektor keuangan yang tidak memiliki data lengkap } \\
\text { mengenai kepemilikan manajerial. }\end{array}$ & $\mathbf{2 7}$ \\
\hline Jumlah perusahaan yang menjadi sampel & $\mathbf{4}$ \\
\hline Jumlah periode pengamatan & $\mathbf{1 0 8}$ \\
\hline Jumlah Pengamatan
\end{tabular}

Sumber: Data diolah peneliti, 2020

Variabel bebas yang digunakan dalam penelitian ini adalah mekanisme corporate governance (kepemilikan intitusional, kepemilikan manajerial, komisaris independen, dan komite audit), leverage, audit tenure, dan kualitas audit. Variabel terikat yang digunakan dalam penelitian ini adalah integritas laporan keuangan.

Teknik analisis data yang digunakan adalah teknik analisis kuantitatif yaitu analisis linear berganda untuk mengetahui atau memperoleh gambaran mengenai pengaruh variabel independen pada variabel dependen dan bertujuan untuk mengestimasi atau memprediksi nilai variabel dependen berdasarkan nilai variabel independen yang diketahui.

\section{HASIL DAN PEMBAHASAN}

Statistik deskriptif disajikan untuk memberikan informasi mengenai variabel-variabel penelitian. Hasil dari uji statistik deskriptif disajikan pada tabel 2. 


\begin{tabular}{lccccc}
\hline \multicolumn{7}{c}{ Tabel 2 } \\
Hasil Uji Statistik Deskriptif & & \\
\hline \multicolumn{1}{c}{ Variabel } & N & Min & Mak & Mean & S. Dev \\
\hline Kepemilikan Institusional (INST) & 108 & 0,10 & 0,99 & 0,77 & 0,33 \\
\hline Kepemilikan Manajerial (MANJ) & 108 & 0,00 & 0,47 & 0,03 & 0,09 \\
\hline Komisaris Independen (KIND) & 108 & 0,33 & 0,80 & 0,55 & 0,12 \\
\hline Komite Audit (KOMAUD) & 108 & 2,0 & 7,00 & 3,68 & 1,17 \\
\hline Leverage (LEV) & 108 & 0,04 & 0,94 & 0,70 & 0,20 \\
\hline Audit Tenure (TENURE) & 108 & 1,00 & 6,00 & 3,38 & 1,58 \\
\hline Kualitas Audit (KUAD) & 108 & 0,00 & 1,00 & 0,45 & 0,50 \\
\hline Integritas Laporan Keuangan (ILK) & 108 & $-0,25$ & 0,21 & $-0,04$ & 0,07 \\
\hline Sur Dan
\end{tabular}

Sumber: Data diolah peneliti (2020)

\section{Analisis Regresi Linier Berganda}

Hipotesis dalam penelitian diuji dengan analisis regresi linier berganda untuk menganalisis variabel bebas terhadap variabel terikat dengan menggunakan program SPSS. Hasil regresi linear berganda dapat dilihat pada tabel 3.

Tabel 3

Hasil Uji Analisis Regresi Linier Berganda

\begin{tabular}{lccc}
\hline \multicolumn{1}{c}{ Variabel } & Beta & t hitung & Sig. \\
\hline Konstanta & 0,038 & 1,059 & 0,292 \\
\hline Kepemilikan Institusional (INST) & 0,029 & 0,885 & 0,378 \\
\hline Kepemilikan Manajerial (MANJ) & 0,011 & 0,138 & 0,891 \\
\hline Komisaris Independen (KIND) & 0,081 & 1,668 & 0,099 \\
\hline Komite Audit (KOMAUD) & 0,003 & 0,492 & 0,624 \\
\hline Leverage (LEV) & $-0,068$ & $-2,038$ & 0,044 \\
\hline Audit Tenure (TENURE) & $-0,010$ & $-2,767$ & 0,007 \\
\hline Kualitas Audit (KUAD) & 0,042 & 5,236 & 0,000 \\
\hline \multicolumn{1}{c}{ Adjusted R $^{2}$} & 0,262 & \\
\hline F hitung & & 6,424 & \\
\hline Sig. F & 0,000 & \\
\hline
\end{tabular}

Sumber: Lampiran 12, data diolah (2020)

\section{Uji Asumsi Klasik}

Uji Normalitas

Hasil perhitungan normalitas dengan uji Kolmogrof-Smirnov menunjukkan nilai Kolmogrof-Smirnov sebesar 0,639 dengan nilai Asymp. Sig (2tailed) sebesar 0,809. Hasil tersebut mengindikasikan bahwa nilai residual dari model regresi ini berdistribusi normal karena nilai Asymp. Sig (2tailed) sebesar 0,809 lebih besar dari 0,05 .

\section{Uji Multikolinieritas}

Hasil uji multikolinearitas menunjukkan masing - masing variabel bebas memiliki nilai tolerance lebih dari $10 \%(0,10)$ dan nilai variance inflation factor (VIF) kurang dari 10. Berdasarkan nilai tolerance dan nilai VIF dari masing masing variabel bebas tersebut, dapat disimpulkan bahwa tidak ada multikolinearitas antar variabel bebas dalam model regresi. 


\section{Uji Autokorelasi}

Hasil uji autokorelasi menunjukkan bahwa nilai DW (Durbin-Watson) sebesar 2,029. Dari nilai tersebut ketentuan yang dipenuhi adalah dU $<\mathrm{dw}<4-\mathrm{dU}$ yaitu $1,8261<2,029<2,1739$ yang artinya nilai dw sebesar 2,029 lebih besar dari nilai dU yaitu 1,8261 namun lebih kecil dari nilai $4-\mathrm{dU}$ yaitu 2,1739 , sehingga dapat disimpulkan bahwa pada model regresi tidak terjadi autokorelasi.

\section{Uji Heterokedastisitas}

Hasil uji Glejser yang digunakan pada penelitian ini tidak terjadi heteroskedastisitas, di mana tingkat signifikansi dari tujuh variabel bebas lebih besar dari 0,05 yaitu kepemilikan institusional (INST) sebesar 0,947, kepemilikan manajerial (MANJ) sebesar 0,613, komisaris independent (KIND) sebesar 0,364, komite audit (KOMAUD) sebesar 0,202 , leverage (LEV) sebesar 0,578 , audit tenure (TENURE) sebesar 0,107 dan kualitas audit (KUAD) sebesar 0,708.

\section{Uji Kelayakan Model}

\section{Hasil Uji Model Fit (Uji F)}

Berdasarkan tabel 3, dapat dijelaskan bahwa nilai $\mathrm{F}$ hitung sebesar 6,424 dengan signifikansi sebesar 0,000. Nilai signifikansi sebesar 0,000 lebih kecil dari 0,05 menunjukkan bahwa variabel independen atau bebas yaitu kepemilikan institusional $\left(\mathrm{X}_{1}\right)$, kepemilikan manajerial $\left(\mathrm{X}_{2}\right)$, komisaris independent $\left(\mathrm{X}_{3}\right)$, komite audit $\left(\mathrm{X}_{4}\right)$, leverage $\left(\mathrm{X}_{5}\right)$, audit tenure $\left(\mathrm{X}_{6}\right)$ dan kualitas audit $\left(\mathrm{X}_{7}\right)$ secara bersama-sama berpengaruh terhadap variabel dependen atau terikat yaitu integritas laporan keuangan yang diproksikan dengan nilai CONNAC.

\section{Koefisien Determinasi $\left(\mathbf{R}^{\mathbf{2}}\right)$}

Koefisien determinasi $\left(\mathrm{R}^{2}\right)$ mengukur seberapa jauh tingkat kemampuan model dalam menjelaskan variasi variabel dependen. Berdasarkan tabel 3, dapat diketahui nilai koefisien determinasi (AdjustedR Square) adalah 0,262 atau sebesar $26,2 \%$. Hal ini berarti sebesar $26,2 \%$ variasi integritas laporan keuangan (ILK) dapat dijelaskan oleh variabel bebas yang terdiri dari kepemilikan institusional (INST), kepemilikan manajerial (MANJ), komisaris independent (KIND), komite audit (KOMAUD), leverage (LEV), audit tenure (TENURE) dan kualitas audit (KUAD). Sedangkan sisanya sebesar $73,8 \%$ dipengaruhi oleh faktor - faktor lain yang tidak dimasukkan kedalam model penelitian.

\section{Hasil Uji t}

Hipotesis

pertama mengemukakan bahwa kepemilikan institusional (INST) berpengaruh positif terhadap integritas laporan keuangan (ILK). Variabel kepemilikan institusional (INST) menunjukkan koefisien regresi sebesar 0,029 , nilai $\mathrm{t}$ hitung 0,885 dengan nilai signifikansi 0,378 yaitu lebih besar dari 0,05. Hasil tersebut menunjukkan bahwa variabel kepemilikan institusional (INST) tidak berpengaruh terhadap integritas laporan keuangan (ILK), sehingga $\mathrm{H}_{1}$ ditolak.

Hipotesis kedua menerangkan bahwa kepemilikan manajerial (MANJ) berpengaruh positif terhadap integritas laporan keuangan (ILK). Variabel kepemilikan manajerial (MANJ) memiliki koefisien regresi sebesar 0,011, nilai $\mathrm{t}$ hitung 0,138 dengan nilai signifikansi sebesar 0,891 dimana nilai tersebut lebih 
besar dari 0,05. Hasil tersebut menunjukkan bahwa variabel kepemilikan manajerial (MANJ) tidak berpengaruh terhadap integritas laporan keuangan (ILK), sehingga $\mathrm{H}_{2}$ ditolak.

Hipotesis

ketiga

mengemukakan bahwa komisaris independen (KIND) berpengaruh positif terhadap integritas laporan keuangan (ILK). Variabel komisaris independen (KIND) menampilkan koefisien regresi sebesar 0,081 , nilai $t$ hitung 1,668 dengan nilai signifikansi sebesar 0,099 dimana nilai tersebut lebih besar dari 0,05 . Hasil tersebut menunjukkan bahwa variabel komisaris independen (KIND) tidak berpengaruh terhadap integritas laporan keuangan (ILK), sehingga $\mathrm{H}_{3}$ ditolak.

Hipotesis

keempat menyebutkan bahwa komite audit (KOMAUD) berpengaruh positif terhadap integritas laporan keuangan (ILK). Variabel komite audit (KOMAUD) memiliki koefisien regresi sebesar 0,003 , nilai $t$ hitung 0,492 dengan nilai signifikansi sebesar 0,624 dimana nilai tersebut lebih besar dari 0,05. Hasil tersebut menunjukkan bahwa variabel komite audit (KOMAUD) tidak berpengaruh terhadap integritas laporan keuangan (ILK), sehingga $\mathrm{H}_{4}$ ditolak.

$$
\text { Hipotesis kelima }
$$

menerangkan bahwa leverage (LEV) berpengaruh negatif terhadap integritas laporan keuangan (ILK). Variabel leverage (LEV) memiliki koefisien regresi sebesar $-0,068$ nilai t hitung -2,038 dengan nilai signifikansi sebesar 0,044 dimana nilai tersebut lebih kecil dari 0,05 . Hasil tersebut menunjukkan bahwa variabel komite audit (KOMAUD) berpengaruh negatif terhadap integritas laporan keuangan (ILK), sehingga $\mathrm{H}_{5}$ diterima.

Hipotesis

keenam menyebutkan bahwa audit tenure (TENURE) berpengaruh negatif terhadap integritas laporan keuangan (ILK). Variabel audit tenure (TENURE) memiliki koefisien regresi sebesar $-0,010$ nilai $t$ hitung $-2,767$ dengan nilai signifikansi sebesar 0,007 dimana nilai tersebut lebih kecil dari 0,05 . Hasil tersebut menunjukkan bahwa variabel audit tenure (TENURE) berpengaruh negatif terhadap integritas laporan keuangan (ILK), sehingga $\mathrm{H}_{6}$ diterima.

Hipotesis

ketujuh menerangkan bahwa kualitas audit (KUAD) berpengaruh positif terhadap integritas laporan keuangan (ILK). Variabel kualitas audit (KUAD) memiliki koefisien regresi sebesar 0,042 nilai t hitung 5,236 dengan nilai signifikansi sebesar 0,000 dimana nilai tersebut lebih kecil dari 0,05 . Hasil tersebut menunjukkan bahwa variabel kualitas audit (KUAD) berpengaruh positif terhadap integritas laporan keuangan (ILK), sehingga $\mathrm{H}_{7}$ diterima.

\section{SIMPULAN DAN SARAN Simpulan}

Penelitian ini menganalisis
pengaruh mekanisme rorporate
governance
(kepemilikan institusional, kepemilikan manajerial, komisaris independen, dan komite audit), leverage, audit tenure dan kualitas audit terhadap integritas laporan keuangan. Sampel dipilih dengan menggunakan metode purposive sampling dan diperoleh sampel sebanyak 27 perusahaan sektor keuangan yang memenuhi kriteria sampel pada periode 20162020 dengantotal 108 amatan. 
Berdasarkan hasil dan pembahasan dapat disimpulkan:

1) Kepemilikan institusional tidak berpengaruh terhadap integritas laporan keuangan. Hal ini disebabkan karena fungsi monitoring yang dilakukan pihak institusi atau lembaga di luar perusahaan terhadap kinerja manajemen kurang efektif. Situasi ini terjadi karena pihak institusi yang memegang banyak saham berperan di luar manajemen perusahaan sehingga berdampak pada sulitnya proses pengawasan.Ini berakibat pada kurangnya pengaruh kepemilikan institusional pada penerapan integritas laporan keuangan.

2) Kepemilikan manajerial tidak berpengaruh terhadap integritas laporan keuangan. Penyebabnya adalah manajemen memiliki peran ganda dalam perusahaan, yaitu sebagai pemilik perusahaan sekaligus sebagai pengelola perusahaan. Hal ini memberikan kesempatan yang lebih besar kepada manajemen untuk melaksanakan hal-hal yang kurang menguntungkan investor seperti mengalokasikan investasi dan membuat keputusan yang cenderung mengutamakan kepentingan manajemen.

3) Komisaris independen tidak berpengaruh terhadap integritas laporan keuangan.Hal ini dikarenakan pemegang saham mayoritas masih memiliki peran utama sehingga independent masih berpihak terhadap kepentingan pemegang saham mayoritas dan mengabaikan kepentingan pemegang saham minoritas, sehingga komisaris independen menjadi tidak independen dalam menjalankan fungsi monitoring. Pengangkatan dan keberadaan komisaris independen dalam perusahaan dilakukan hanya sebagai pemenuh regulasi dan peraturan pemerintah saja, tetapi belum dapat berfungsi untuk menegakkan tata kelola yang baik.

4) Komite audit tidak berpengaruh terhadap integritas laporan keuangan. Hal ini dipicu keberadaan komite audit dalam perusahaan dianggap kurang efektif karena belum bisa memaksimalkan fungsinya dalam praktik akuntansi. Komite audit dianggap hanya melakukan penelaahan atas informasi keuangan dan data akuntansi yang sudah disusun perusahaan, namun tidak terlibat secara langsung dalam penyusunan laporan keuangan dan penyelesaian masalah keuangan yang dihadapi perusahaan. Komite audit hanya menjadi pelengkap untuk memenuhi aturan yang berlaku.

5) Leverage berpengaruh negatif terhadap integritas laporan keuangan. Hal ini dikarenakan tingginya leverage perusahaan turut meningkatkan risiko yang dihadapi investor sehingga perusahaan dituntut 
memperoleh keuntungan yang besar. Situasi ini memotivasi manajemen untuk melakukan manajemen laba sehingga menurunkan integritas laporan keuangan. Hasil ini mengindikasikan risiko keuangan tinggi akan memperlambat manajemen dalam menginformasikan kinerja perusahaan dan meningkatkan upaya manipulasi laporan keuangan.

6) Audit tenure berpengaruh negatif terhadap integritas laporan keuangan. Hal ini dikarenakan audit tenure yang panjang akan menimbulkan kedekatan yang berakibat pada menurunnya kualitas auditor dalam mengaudit laporan keuangan klien. Lamanya masa perikatan auditor dengan klien berpotensi mengurangi independensi, kualitas audit serta objektivitas auditor. Auditor condong menyesuaikan dengan berbagai keinginan pihak manajemen perusahaan. Audit tenure inilah yang diindikasi dapat menyebabkan penurunan atas integritas laporan keuangan.

7) Kualitas audit berpengaruh positif terhadap integritas laporan keuangan.KAP yang besar

akancenderungmenyediakan kualitas audit yang lebih baik dibandingkan dengan KAP lebih kecil. Hal ini dikarenakan jika KAP yang besar tidak memberikan kualitas audit yang tinggi, KAP tersebut akan kehilangan reputasi dan kliennya.Selain

itu untuk menghasilkan
kualitas audit yang baik,
auditor perlu menempuh
pelatihan-pelatihan $r$ untuk
mengasah kemampuannya.
Pelatihan khusus akan
meningkatkan mutu personal
serta meningkatkan keahlian
khusus auditor di sebuah
bidang sekaligus
meningkatkan integritas
laporan yang disusun.

Saran

Berdasarkan hasil penelitian, perusahaan diharapkan lebih memperhatikan besarnya hutang perusahaan, karena dalam penelitian ini terbukti bahwa besarnya hutang dapat menurunkan tingkat integritas laporan keuangan. Selain itu, perusahaan disarankan menggunakan jasa audit dari auditor yang sudah berpengalaman dan membatasi waktu kerja sama dengan auditor sehingga auditor dapat menjalankan fungsinya secara independen dalam memeriksa laporan keuangan sehingga tingkat integritas laporan keuangan dapat ditingkatkan.

\section{DAFTAR PUSTAKA}

Adhitya, T. R. 2018. Pengaruh Komisaris Independen, Komite Audit, Kualitas Audit, dan Leverage Terhadap Integritas Laporan Keuangan dengan Firm Size Sebagai Variabel Moderasi pada Perusahaan Pertambangan yang Terdaftar di Bursa Efek Indonesia.Tesis. Universitas Sumatera Utara.

Ariastini, I. D. A. P. 2017. Pengaruh Corporate Governance 
Journal of Applied Management and Accounting Science. (JAMAS)

(Ida Ayu Ratih Manuari, Ni Luh Nyoman Sherina Devi 116 - 131)

Vol 2, No 2, Juni 2021

Terhadap Integritas Laporan

Keuangan pada Perusahaan

Manufaktur yang Terdaftar di

BEI Tahun 2013-2015.

Skripsi. Universitas

Mahasaraswati Denpasar.

Badewin. 2019. Pengaruh Kepemilikan Institusional, Komite Audit Dan Kualitas Audit Terhadap Integritas Laporan Keuangan Pada Perusahaan Manufaktur Yang Terdaftar Di Bei. Jurnal Akuntansi Dan Keuangan, 8(1), 5-10.

Balina, I. 2015. Pengaruh Mekanisme Good Corporate Governance (GGC) Terhadap Integritas Laporan Keuangan (Studi Empiris pada Perusahaan Manufaktur yang Terdaftar di Bursa Efek Indonesia Periode 2009-2013).

Skripsi.

Universitas Mahasaraswati Denpasar.

Fajaryani, A. 2015. Analisis FaktorFaktor yang Mempengaruhi Integritas Laporan Keuangan (Studi Empiris pada Perusahaan Pertambangan yang Terdaftar di Bursa Efek Indonesia Periode 20082013).Skripsi. Universitas Negeri Yogyakarta.

FCGI. 2001. Seri Tata Kelola Perusahaan (Corporate Governance) (2nd ed.).

Gayatri, I. A. S., \& Suputra, I. D. G. D. 2013. Pengaruh Corporate Governance, Ukuran

Perusahaan Dan Leverage Terhadap Integritas Laporan
Keuangan.

Akuntansi, 5(2), 345-360.

Giovani, N. K. A. 2016. Pengaruh Mekanisme Corporate Governance Terhadap Integritas Laporan Keuangan pada Perusahaan Pertambangan yang Terdaftar di Bursa Efek Indonesia Periode 2010-2014.Skripsi. Universitas Mahasaraswati Denpasar.

Hardiningsih, P. 2010. Pengaruh Independensi, Corporate Governance, dan Kualitas Audit Terhadap Integritas Laporan Keuangan. Kajian Akuntansi, 2(1), 228-61-76. https://doi.org/10.1117/12.262 835

Ikatan Akuntan Indonesia. 2013. Exposure Draft Pernyataan Standar Akuntansi Keuangan, Penyajian Laporan Keuangan. Ikatan Akuntan Indonesia.

Ismail, A. G. 2018. Analisis Pengaruh Ukuran Perusahaan, Audit Tenure, Kepemilikan Manajerial dan Komisaris Independen Terhadap Integritas Laporan Keuangan (Studi empiris pada Perusahaan Property, Real Estate, dan Building Construction yang Terdaftar di Bursa Efek Indonesia.Skripsi. Universitas Islam Indonesia.

Jensen, M. C., \& Meckling, W. H. 1976. Theory of the Firm: Managerial Behavior Agency Cost and Ownership Structure. 
Journal of Finance Economic, 3, 305-360.

Kasmir. 2016. Pengantar Manajemen Keuangan (2nd ed.). Kencana Prenada.

Lestari, I. A. C. M. 2015. Pengaruh Audit Tenure, Fee Audit, dan Kualitas Audit Terhadap Integritas Laporan Keuangan Perusahaan Manufaktur di Bursa Efek Indonesia. Skripsi. Universitas Mahasaraswati Denpasar.

Nilawati, D. P. 2018. Pengaruh Mekanisme Corporate Governance Terhadap Integritas Laporan Keuangan pada Perusahaan Manufaktur yang Terdaftar di Bursa Efek Indonesia Periode 2013-2015. Skripsi. Universitas Mahasaraswati Denpasar.

Pradani, Y. A. 2017. Pengaruh Mekanisme Corporate Governance, Leverage dan Pergantian Auditor terhadap Integritas Laporan Keuangan (Studi Empiris pada Perusahaan Manufaktur yang terdaftar di Bursa Efek Indonesia tahun 20102015).Publikasi Ilmiah. Universitas Muhammadiyah Surakarta.

Pratiwi, Y. 2019. Pengaruh Audit Tenure, Ukuran Auditor, dan Spesialisasi Industri Auditor Terhadap Integritas Laporan Keuangan pada Perusahaan Manufaktur yang Tercatat di Bursa Efek Indonesia (BEI). Skripsi.
Muhammadiyah Sumatera Utara.

Saad, B., \& Abdillah, A. F. 2019. Analisis Pengaruh Ukuran Perusahaan, Leverage, Audit Tenure, Dan Financial Distress Terhadap Integritas Laporan Keuangan. Jurnal Ilmu Manajemen Oikonomia, 15(1), 70-85. http://journal.unas.ac.id/oikon amia/article/view/645/525

Santia, A. D., \& Afriyenti, M. 2019. Analisis Pengaruh Mekanisme Corporate Governance Dan Audit Tenure Terhadap Integritas Laporan. Jurnal Eksplorasi Akuntansi, 1(3), 1224-1258.

Sartono, A. 2008. Manajemen Keuangan: Teori dan Aplikasi (4th ed.). BPFE.

Setiawan, K. N. 2016. Pengaruh Mekanisme Corporate Governance, Audit Tenure, dan Ukuran Perusahaan Terhadap Integritas Laporan Keuangan.Skripsi. Universitas Islam Negeri Syarif Hidayatullah.

Susiana, \& Herawaty, A. 2007. Analisis Pengaruh Independensi, Mekanisme Corporate Governance dan Kualitas Audit Terhadap Integritas Laporan Keuangan. Simposium Nasional Akuntansi X Tahun 2007, 1(1).

Susiwo. 2018. Pengaruh Komisaris Independen, Kepemilikan Institusional, Komite Audit, 
Journal of Applied Management and Accounting Science. (JAMAS)

(Ida Ayu Ratih Manuari, Ni Luh Nyoman Sherina Devi 116 - 131)

Vol 2, No 2, Juni 2021

Ukuran KAP, dan Leverage

Terhadap Integritas Laporan

Keuangan pada Perusahaan

Manufaktur yang Terdaftar di

Bursa Efek Indonesia pada

Periode 2014-2016.Skripsi.

Universitas Stikubank

(Unisbank).

Suyitno, A. A. 2016. Pengaruh Mekanisme Corporate Governance, Audit Tenure, dan Kualitas Audit Terhadap Integritas Laporan Keuangan (Studi Empiris pada Perusahaan Manufaktur yang Terdaftar di Bursa Efek Indonesia Periode 20122014).Skripsi. Universitas Mahasaraswati Denpasar.

Tristiarini, N. 2005. Pengaruh Penerapan Corporate Governance Terhadap Abnormal Return pada saat Pengumuman Laporan Keuangan 2003.Tesis. Universitas Diponegoro Semarang.

Tussiana, A. A., \& Lastanti, H. S. 2017. Pengaruh Independensi, Kualitas Audit, Spesialisasi Industri Auditor Dan Corporate Governance Terhadap Integritas Laporan Keuangan. Media Riset Akuntansi, Auditing Dan Informasi, $16(1), \quad 69$. https://doi.org/10.25105/mraai .v16i1.2076

Verya, E., Indrawati, N., \& Hanif, R. 2016. Analisis Pengaruh Ukuran Perusahaan, Leverage Dan Good Corporate Governance Terhadap
Integritas Laporan Keuangan

(Studi Empiris pada

Perusahaan Manufaktur yang Listing di Bursa Efek Indonesia Periode Tahun 2012-2014). Jurnal Online Mahasiswa Fakultas Ekonomi Universitas Riau, 4(1), 982996.

Yulinda, N., Nasir, A., \& Idrus, R. 2016. Pengaruh Komisaris Independen, Komite Audit, Leverage, Pergantian Auditor, dan Spesialisasi Industri Auditor Terhadap Integritas Laporan Keuangan (Studi Empiris Pada Perusahaan Manufaktur Yang Terdaftar di BEI Tahun 2010-2013). Jurnal Online Mahasiswa Fakultas Ekonomi Universitas Riau, 3(1), 419-433. 